\section{Call for more open councils}

REFORM of Britain's research councils is called for in a new report from a body representing more than two-thirds of university teaching and research staff. The Association of University Teachers (AUT) wants to see more open research councils among a host of other changes it claims are necessary to deal with the "crisis" in university research.

The crisis is attributed to the breakdown of the dual-funding system. Although the universities carry out more than half of all basic research in the United Kindgom, the budget supplied through the University Grants Committee (UGC) (to maintain "well-founded"laboratories) and the five research councils (to support research projects) has declined in real terms while the costs of research are rising rapidly. Increasing numbers of researchers are joining the brain drain; libraries have had to cut back book purchases by 40 per cent since the 1970s; the student/staff ratio has deteriorated; and an increasing percentage of researchers face an uncertain life on short-term contracts.

The fight put up by UGC and the research councils to try to remedy matters seems not to have impressed AUT. UGC's new policy of trying to assess the quality of research carried out at different university departments and to concentrate scarce resources at those rated highly is seen as exacerbating the effects of the cuts and is "emphatically rejected". Selectivity, the report says, favours those areas in which short-term returns can be easily identified while university research should be of the "fundamental kind" from which "major breakthroughs rather than marginal advances result". The effect of selectivity may undermine university autonomy and create a hierarchy of universities.

The five research councils come in for some criticism. Their "success in predicting growth areas in research has not been great", the report says. The councils are appointed by the Secretary of State but AUT believe they should be more directly representative of scientists. Nominations to the councils and their committees should be by learned societies and regular open meetings held to discuss priorities in research funding. Particular difficulties now arise because not all research proposals rated "alpha" (to be funded "at all costs") by peer review can now be funded. In that sense the report says "peer review has broken down" and personal views may be substituted. Safeguards to ensure that committee members do not receive preferential treatment, and full explanations of all decisions, including the reasons for choices between applicants, given publicly, are called for.

The Advisory Board for the Research

\section{Creation science}

Councils (ABRC) could also be made more open, the report says. Each year, in its advice to government, the board has protested more strongly about the parlous condition of the universities. But the government shows little sign of listening. To add clout the report suggests that Parliament be given the right to discuss the advice of ABRC and to cross-question it. Whether this could be done without changing ABRC's status is not yet clear.
An additional body is needed as a national forum to discuss research and development policy. The National Economic Development Council, an organization with representation from government, industry and unions, would be suitable.

British industry is seen as needing encouragement to commission research in the universities: there is evidence that foreign industrial investment in British universities exceeds that of British companies. Changes in tax-exemption rules and the establishment of a fund to help small firms sponsor university research are possible solutions.

\title{
Nobel laureates go into battle
}

\section{Washington}

SEVENTY-TwO US Nobel laureates have signed a brief filed with the Supreme Court this week urging the court to declare unconstitutional a Louisiana law requiring balanced treatment of evolution and creation in state schools. According to organizers of the brief, this is the largest group of Nobel laureates ever to sign a single document.

The Supreme Court agreed in May to hear arguments on the constitutionality of the Lousiana statute. In 1982, a federal district court struck down a similar Arkansas law because definitions in the law made it clear that creation science was directly derived from descriptions of creation in the Bible. The Louisiana statute removed the specific definitions of what creation science is, leaving only the tautology that creation science means "the scientific evidences $[s i c]$ for creation". The Nobel laureates' brief sets out to show that the Louisiana statute originally included language similar to the Arkansas statute, but lawmakers altered it after the Arkansas decision. The brief further attacks the law for singling out evolution as a theory, rather than emphasizing the uniformly tentative nature of science and argues that by creating a distinction between scientific

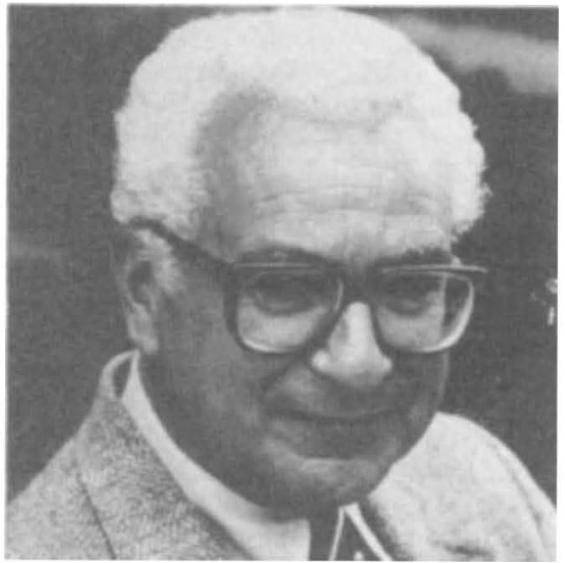

Murray Gell-Mann, one of the laureates leading the fight against the "forces of darkness".

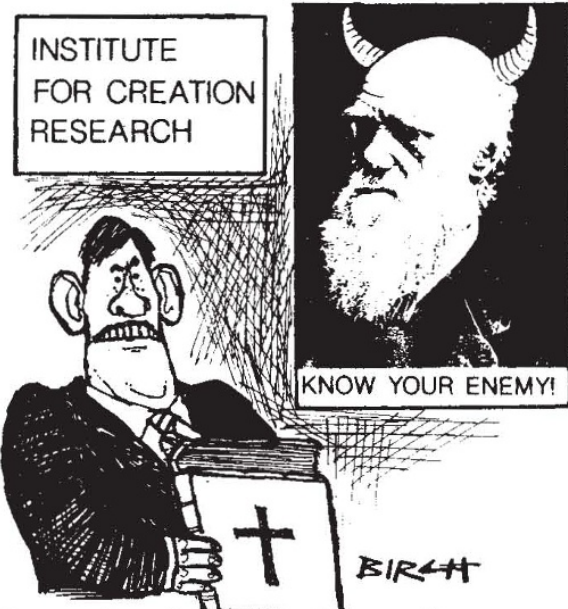

fact and evolutionary theory. the statute implicitly tells schoolchildren that "while most of what they learn in science class is "proven scientific fact', evolution is not".

Murray Gell-Mann, who won the Nobel prize for physics in 1969, says it is not just biological science that has come under attack from creationists. Gell-Mann feels the Lousiana act represents a "grave danger to the Republic," one that will result in a decreased ability of schoolchildren to deal with scientific issues. Francisco Ayala, director of the Institute of Ecology at the University of California at Davis and a member of the National Academy of Sciences committee on science and creationism, agrees that nothing less than the "survival of rationality in this country's schools" is at stake. The Academy is preparing its own brief. Duana Gish. vicepresident of the Institute for Creation Research (ICR) says his organization has not taken a position on the Supreme Court case.

The Supreme Court will hear oral arguments in the case sometime late this year or early next. Frank Press, president of the National Academy of Sciences says the debate should not be taken lightly. According to Gell-Mann, it is the "old struggle of science against the forces of darkness".
Joseph Palca 